\title{
The Differential Diagnosis of “Tigroid Pattern” on Brain Magnetic Resonance Imaging: A Case Report
}

\author{
Beyin Manyetik Rezonans Görüntülemesinde İzlenen “Kaplan Derisi” Görünümünün
} Ayırici Tanisi: Olgu Sunumu

\author{
(1) Nihan Hande Akçakaya \\ Turkey Spastic Children Foundation, Istanbul, Turkey
}

Keywords: Metachromatic leukodystrophy, tigroid pattern, ARSA, exome sequencing

Anahtar Kelimeler: Metakromatik lökodistrofi, kaplan derisi görünümü, $A R S A$, ekzom dizileme

\section{Dear Editor,}

A two-year-old girl who had no consanguinity between her parents was evaluated with symptoms of imbalance and an inability to walk. It was learned that the patient's motor and mental development was timely, but deterioration was observed when she was 15 months old. The cranial and spinal magnetic resonance imaging (MRI) scans, cerebrospinal fluid, tandem mass spectrometry, and urine organic acid analysis of the patient at the $19^{\text {th }}$ month were normal. At the age of two years, she had truncal ataxia and symmetrical spasticity and pyramidal findings detected only on the lower extremities. Spontaneous extension of the toes was remarkable. There was no retinal pathology in the eye examination. Considering the rapid progression of the patient, the patient was referred for clinical exome sequencing, a method that allows genetic diagnosis of rare diseases such as hereditary spastic paraparesis, and leukodystrophies. As a result, two known mutations (c.114C $>\mathrm{T}$; p.Arg372Trp and c.418dupC; p.His140Profs36*) were identified in the ARSA gene that led to metachromatic leukodystrophy (MLD) with combined heterozygosity. The patient was genetically diagnosed as having MLD and T2-weighted images showed marked periventricular white matter lesions in the parieto-occipital region consistent with MLD in the $30^{\text {th }}$ month follow-up cranial MRI (Figure 1A, 1B). The patient's clinical progression was consistent with leukodystrophy, followed by cognitive deterioration and loss of speech, spastic tetraparesis, peripheral nerve neuropathy, and seizures.

MLD is a neurodegenerative disease caused by lysosomal arylsulfatase enzyme deficiency due to ARSA gene mutations.
The incidence of MLD is 1 per 100.000 live births. Hydrolysis of sulfated glycophospholipids, known as sulfatides, is not possible due to a lack of enzyme. The disease is characterized by symptoms associated with the accumulation of sulfatides, especially in myelin and the biliary tract. MLD has three different types: late infantile, juvenile, and adult. The most common type is the late infantile type, which starts between 15 months and two years of age. The definitive diagnosis of MLD is based on the detection of ARSA gene mutations associated with clinical findings or an increase in urinary sulfatide output, or by demonstration of metachromatic lipid accumulation in the nerve or peripheral nerves. Other findings and tests are supportive. The decrease in lysosomal ARSA enzyme activity may be misleading due to the pseudo-deficiency observed in the normal population (1). There is no specific MRI finding in MLD. Diffuse symmetric periventricular dysmyelinating lesions in which subcortical U-fibers and cerebellar white matter are preserved in MRI, especially on T2-weighted sequence, can be seen in other types of leukodystrophy such as Pelizeus-Merzbacher or adrenoleukodystrophy. In addition to the white matter lesions, radial stripes are usually observed around the circular foci. This involvement is likened to the appearance of a tiger skin (tigroid pattern) (2). The tigroid pattern in our patient was not a disease-specific appearance. In addition to MLD, this pattern is observed in single gene diseases that disrupt myelin tissue such as Pelizaeus-Merzbacher, globoid cell leukodystrophy, and GM1 gangliosidosis $(2,3)$. It has also been reported in chromosomal anomalies and genetic diseases that causes to neuronal migration

\footnotetext{
Address for Correspondence/Yazışma Adresi: Nihan Hande Akçakaya MD, Turkey Spastic Children Foundation, Istanbul, Turkey Phone: +90 8502200707 E-mail: nhakcakaya@gmail.com ORCID ID: orcid.org/0000-0001-8414-4017 Received/Geliş Tarihi: 27.12.2018 Accepted/Kabul Tarihi: 03.03.2019

${ }^{\oplus}$ Copyright 2019 by Turkish Neurological Society Turkish Journal of Neurology published by Galenos Publishing House.
} 

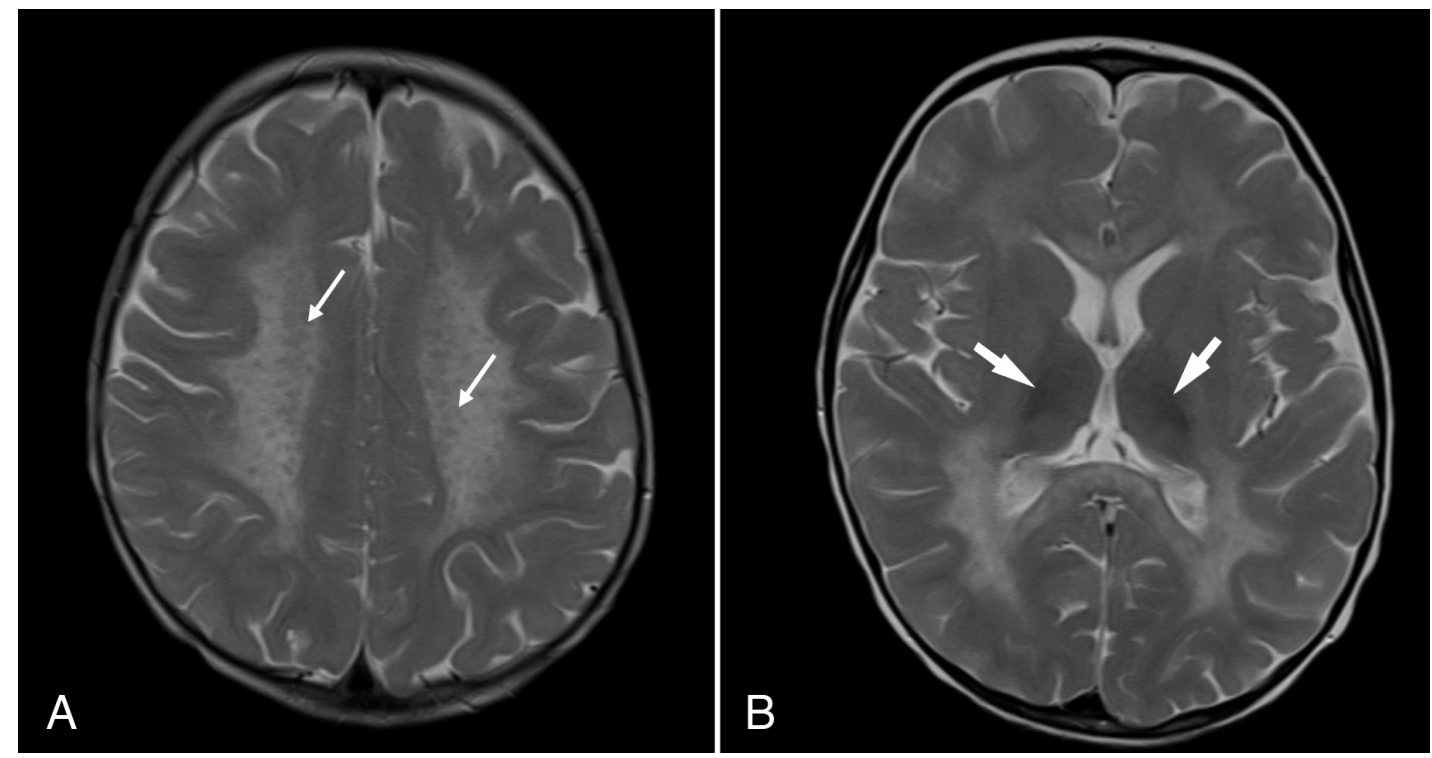

Figure 1. A) In addition to the hyperintense appearance of white matter, diffuse circular hypointensities and radial lines (white arrows) are observed with hyperintensity on T2-weighted axial section passing through the level of the centrum semiovale. B) The white matter involvement is evident in the parieto-occipital region on T2-weighted axial section passing through the level of thalamus. A hypointense appearance of the thalamus (yellow arrows) is a finding in lysosomal storage diseases

defect (4). In addition to hereditary diseases, it has also been reported in acute disseminated encephalomyelitis, which is an acquired myelin disease (5). This pattern is thought to be due to the relative preservation of myelinated fibers in the vicinity of the vein (3).

Spastic paraparesis and ataxia in the patient without any radiologic findings necessitates the differential diagnosis of many neurologic diseases. Clinical diagnosis of many diseases at the time of only examination findings creates difficulties for the patient and the physician. In cases where the disease is not due to infection, trauma or vascular cause, appropriate genetic tests in selected patients provide fast and reliable results.

Ethics

Informed Consent: Written informed consent was taken from the parents for reporting this case.

Peer-review: Internally peer-reviewed.
Financial Disclosure: The author declared that this study received no financial support.

\section{References}

1. Liaw HR, Lee HF, Chi CS, Tsai CR. Late infantile metachromatic leukodystrophy: Clinical manifestations of five Taiwanese patients and Genetic features in Asia. Orphanet J of Rare Dis 2015;10:144.

2. Cheon JE, Kim IO, Hwang YS, et al. Leucodystrophy in children: a pictorial review of MR imaging features. Radiographics 2002;22:461-476.

3. Van der Voorn JP, Pouwels PJ, Kamphorst W, et al. Histopathologic correlates of radial stripes on MR images in lysosomal storage disorders. Am J Neuroradiol 2005;26:442-446.

4. Balasubramanian M, Smith K, Williams S, et al. Tigroid pattern of cerebral white matter involvement in chromosome 6p25 deletion syndrome with concomitant 5p15 duplication. J Pediatr Genet 2012;1:247-252.

5. Pradhan S, Das A. Tigroid and leopard skin appearance in acute disseminated encephalomyelitis. Neurol India 2018;66:1172-1174. 